Science, Technology and Development 35 (2): 94-97, 2016

ISSN 0254-6418 / DOI: 10.3923/std.2016.94.97

(C) 2016 Pakistan Council for Science and Technology

\title{
Seedling Age Impact on Growth and Yield of Bitter Gourd
}

\author{
Ghulam Jellani, Muhammad Jawaad Atif, Hidayat Ullah, Taj Naseeb Khan and Noor Saleem \\ Department of Horticultural Research and Development, Directorate of Vegetable, \\ National Agricultural Research Centre, Islamabad, Pakistan
}

\begin{abstract}
Field experiments were conducted to determine the growth and yield of bitter gourd in response to seedling age during the years 2011 and 2012. Minimum days to 1st picking, maximum availability period, yield and net profit were observed in 40 days old seedlings and 100\% survival rate was observed in all three (40, 50 and 60 days) ages of seedlings. Seedlings of varying ages did not fluctuate greatly in yield and yield components in the field, although, all seedlings had higher early yields than the directly seeded controls. Maximum gross margin (US $\$ 1777.7 \mathrm{ha}^{-1}$ ) was achieved in 40 days old seedling as compared to direct seeded crop (US \$337.5 ha-1). Results from these experiments suggest that 40 days may be reasonable target age for transplanting bitter gourd seedlings.
\end{abstract}

Key words: Cucurbits, bitter gourd, early crop and seedling

\section{INTRODUCTION}

Bitter gourd (Momordica charantia L.) is one of the most popular vegetables in Southeast Asia. It is a member of the cucurbitaceous family along with cucumber, squash, watermelon and muskmelon. Native to China or India, the fast-growing vine is grown throughout Asia and is becoming popular worldwide (Palada and Chang, 2003). In Pakistan, bitter gourd is cultivated at an area of 6107 hectares with an annual production of $57190 \mathrm{t}$ (GOP., 2014). Seedlings are used comprehensively to establish a range of vegetable crops, including cucurbit species. Considerable research has been conducted concerning production, quality and establishment of vegetable transplants, particularly for certain solanaceous, cruciferous and cucurbit crops (Hall, 1989). The performance of any crop depends upon the quality of the seed used for sowing, various environmental factors, type of cultivar and cultural practices, etc. Among all these factors, optimum age of seedling is one of the factors, which affect growth and yield, but generally, this factor is ignored by the farmers. The optimum seedling age depends on the soil, environmental factors (temperature, moisture), location and cultural practices (Weston, 1988). Best possible vegetable crop production can only be accomplished if successful stand establishment is achieved first, as each plant contributes to total crop yield (Orzolek, 1996). Many vegetable growers use seedlings to improve stand establishment. Some advantages of using seedlings as compared to direct seeding of crops include more proficient use of expensive hybrid seed, prevention of adverse environments such as cool soils, enlarged crop uniformity and improved earliness of crop productivity (NeSmith and Duval, 1998). Successful use of transplanted seedlings depends largely on the ability of the plants to resume growth rapidly following transplanting (McKee, 1981). Several studies have compared yields and above-ground growth of seedlings and direct seeded cucurbit crops (Hall, 1989; NeSmith and Duval, 1998). The rate of root production has a direct influence on nutrient acquirement and successive crop yield (Barber and Silberbush, 1984). The type of root system developed for seedlings can differ from that of direct seeded plants, mainly for crops having a prominent tap root system (Leskovar and Stoffella, 1995). The growth and development of roots and shoots are in proportion and any disorder to their proportion can change crop growth (Taylor and Arkin, 1981). Several investigations have concentrated on the influence of seedling age on subsequent crop performance. The objective of this research was to examine the effect of seedling age on growth and yield of bitter gourd.

\section{MATERIALS AND METHODS}

Experiments were conducted at Directorate of Vegetable, DHRD, NARC, Islamabad, during 2011 and 2012. Location of experimental site is at $73.08^{\circ}$ (longitude), $33.42^{\circ}$ (latitude) and $683 \mathrm{msl}$ (Elevation). Bitter gourd was transplanted or direct seeded in the field in a randomized complete block design (RCBD) with three replications. Following four treatments were made in spring 2011 and 2012 under field condition. $\mathrm{T}_{0}$ : Traditional direct sowing practice, $\mathrm{T}_{1}$ : 40 days old 
seedlings, $\mathrm{T}_{2}: 50$ days old seedlings, $\mathrm{T}_{3}: 60$ days old seedlings. Farm Yard Manure @ $7 \mathrm{t} \mathrm{ha}^{-1}$ was included in soil as organic amendment for transplanting of seedlings. Seeds of bitter gourd var. (Faisalabad long) were sown in plastic tubes in traditional practicing media of FYM, sand and soil in proportion of 1:1:1, respectively and were germinated under plastic tunnels. Nursery of bitter gourd was transplanted during first week of March, 2011 and 2012 with row to row and plant to plant distance was maintained at $1.5 \mathrm{~m}$ and $50 \mathrm{~cm}$, respectively. Data were collected on days to 1st picking, availability period, survival (\%), yield plant ${ }^{-1}(\mathrm{gm})$, yield $\left(\mathrm{t} \mathrm{ha}^{-1}\right)$, gross return ha ${ }^{-1}$ and gross margin ha ${ }^{-1}$. Means of the examined traits were ranked according to Least Significant Difference (LSD) Test (Steel et al., 1997). The experiment was replicated thrice. The data were analyzed using Statistix 8.1 software package.

\section{RESULTS AND DISCUSSION}

Days to 1st picking, availability period and survival (\%): Results indicated days to 1st picking having significant difference with minimum days (40.33) for 40 days old seedlings and maximum days (80.50) for direct seeded plants. The mean values gave significant results with maximum (86.50) and minimum (51.50) availability period for 40 days old seedlings and direct seeded plants, respectively. Survival rate showed

Table 1: Meteorological data during the study period of 2011 and 2012

\begin{tabular}{lcccr}
\hline Period of study & $\begin{array}{l}\text { Max temp } \\
\left({ }^{\circ} \mathrm{C}\right)\end{array}$ & $\begin{array}{l}\text { Min temp } \\
\left({ }^{\circ} \mathrm{C}\right)\end{array}$ & $\begin{array}{l}\text { Relative } \\
\text { humidity }(\%)\end{array}$ & $\begin{array}{l}\text { Rainfall } \\
(\mathrm{mm})\end{array}$ \\
\hline January (2011) & 17.3 & 1.8 & 71.3 & 8.32 \\
February (2011) & 17.7 & 5.8 & 75.8 & 78.73 \\
March (2011) & 25.8 & 10.2 & 63 & 53.19 \\
April (2011) & 28.8 & 13.5 & 61 & 53.96 \\
May (2011) & 38.1 & 20.4 & 45 & 17.29 \\
January (2012) & 16.9 & 1.32 & 68.5 & 59.06 \\
February (2012) & 17.4 & 3.24 & 70.1 & 44.12 \\
March (2012) & 24.9 & 8.9 & 58.6 & 15.95 \\
April (2012) & 29.9 & 15.0 & 54.7 & 40.93 \\
May (2012) & 26.2 & 18.3 & 38.4 & 9.47 \\
\hline
\end{tabular}

Max temp: Maximum temperature, Min temp: Minimum temperature, Source: Metrological Section, Water Resources Research Institute (WRRI), NARC, Islamabad significantly higher difference (100\%) in all three (40, 50 and 60) age of seedlings as compared to direct seeded plants (81.67\%). Higher survival rate also increases per unit area production of bitter gourd (Table 2). First picking was greater for transplanted plants as compared to direct seeded crop. Less yield of direct seeded crop might be due to the effect of weather pattern on pollinator activity and successive fruit set (NeSmith and Duval, 1998). Singh et al. (2010) also verified the method of raising seedlings for early harvesting of cucurbits in India. Minimum survival rate in direct seeded crop might be due to reduced root growth. Lowest survival of bitter gourd crop in direct sowing method was also noted by Handley and Hutton (2003). Nonetheless, all seedling treatments showed statistically parallel for all above described variables. These results are also supported by Hasandokht and Nosrati (2010). It is also evident from the two years mean values that seedlings regardless of their age produced fruits earlier compared to direct seeded crop (Table 2). The difference in days to first picking during both years might be due to variation in temperature (Table 1). The higher temperature during growth period improved the early production of pistillate flowers leading to early harvesting. NeSmith et al. (1994) also described that production of pistillate flowers in summer squash was enhanced by high temperature. Maximum survival rate contributed to increase production per unit area of bitter gourd.

Yield, gross return and margin: Table 3 shows that 40 days old seedlings have maximum (1210.4 gm) yield plant ${ }^{-1}$ and in direct sowing method minimum (678.9) yield plant ${ }^{-1}$ was observed having significant difference in all treatments. Yield $\left(\mathrm{t} \mathrm{ha}^{-1}\right)$ showed significant difference in all treatments with maximum (17.93) and minimum (8.20) yield $\mathrm{t} \mathrm{ha}^{-1}$ in 40 days old seedling and direct sowing method, respectively (Table 3 ). The maximum gross return ha ${ }^{-1}$ US (\$) 3600.4 was obtained from 40 days old seedling while minimum gross return ha ${ }^{-1}$ US (\$) 1876.4 was recorded in direct sowing method and maximum gross margin ha ${ }^{-1}$ US (\$) 1777.7 was obtained from 40 days

Table 2: Seedling age response to days to 1st picking, availability period and survival of bitter gourd

\begin{tabular}{|c|c|c|c|c|c|c|c|c|c|}
\hline \multirow[b]{2}{*}{ Treatments } & \multicolumn{3}{|c|}{ Days to 1st picking } & \multicolumn{3}{|c|}{ Availability period (days) } & \multicolumn{3}{|c|}{ Survival rate of plants (\%) } \\
\hline & 2011 & 2012 & Mean & 2011 & 2012 & Mean & 2011 & 2012 & Mean \\
\hline Direct sowing & 78.33 & 82.67 & 80.50 & 41.67 & 61.33 & 51.50 & 86.67 & 76.67 & 81.67 \\
\hline 40 days old seedlings & 39.00 & 41.67 & 40.33 & 81.00 & 92.00 & 86.50 & 100 & 100 & 100 \\
\hline 50 days old seedlings & 42.67 & 47.33 & 45.00 & 77.33 & 93.33 & 85.33 & 100 & 100 & 100 \\
\hline 60 days old seedlings & 44.67 & 49.00 & 46.83 & 75.33 & 96.00 & 85.67 & 100 & 100 & 100 \\
\hline Year means & 51.17 & 55.17 & & 68.83 & 85.67 & & 94.67 & 94.16 & \\
\hline $\mathrm{I} S \mathrm{C}$ & Treatment & Year & Interaction & Treatment & Year & Interaction & Treatment & Year & Interaction \\
\hline
\end{tabular}

*NS: Non-significant 
Sci. Technol. Dev., 35 (2): 94-97, 2016

Table 3: Seedling age response to yield variables from bitter gourd

\begin{tabular}{|c|c|c|c|c|c|c|}
\hline \multirow[b]{2}{*}{ Treatments } & \multicolumn{3}{|c|}{ Yield plant ${ }^{-1}(\mathrm{gm})$} & \multicolumn{3}{|c|}{ Yield $\left(\mathrm{t} \mathrm{ha}^{-1}\right)$} \\
\hline & 2011 & 2012 & Mean & 2011 & 2012 & Mean \\
\hline Direct sowing & 669.4 & 688.4 & 678.9 & 8.60 & 7.80 & 8.20 \\
\hline 40 days old seedlings & 1195.0 & 1225.7 & 1210.4 & 17.70 & 18.17 & 17.93 \\
\hline 50 days old seedlings & 910.0 & 921.6 & 915.8 & 13.47 & 13.63 & 13.55 \\
\hline 60 days old seedlings & 788.3 & 855.9 & 822.1 & 11.70 & 12.70 & 12.20 \\
\hline \multirow[t]{2}{*}{ Year's mean } & 890.67 & 922.92 & & 12.87 & 13.07 & \\
\hline & Treatment & Year & Interaction & Treatment & Year & Interaction \\
\hline LSD & 100.55 & $*$ NS & *NS & 1.53 & $* \mathrm{NS}$ & *NS \\
\hline
\end{tabular}

*NS: Non-significant

Table 4: Seedling age response to gross return and margin from bitter gourd

\begin{tabular}{|c|c|c|c|c|c|c|}
\hline \multirow[b]{2}{*}{ Treatments } & \multicolumn{3}{|c|}{ Gross return ha ${ }^{-1}$ (US\$) } & \multicolumn{3}{|c|}{ Gross margin $\mathrm{ha}^{-1}$ (US\$) } \\
\hline & 2011 & 2012 & Mean & 2011 & 2012 & Mean \\
\hline Direct sowing & 2037.0 & 1715.8 & 1876.4 & 448.8 & 226.3 & 337.5 \\
\hline 40 days old seedlings & 3199.4 & 4001.5 & 3600.4 & 1318.3 & 2237.2 & 1777.7 \\
\hline 50 days old seedlings & 2703.4 & 3008.8 & 2856.1 & 822.2 & 1244.5 & 1033.4 \\
\hline 60 days old seedlings & 2491.6 & 2794.2 & 2642.9 & 610.5 & 1030.0 & 820.2 \\
\hline \multirow[t]{2}{*}{ Year's mean } & 2607.8 & 2880.1 & & 799.9 & 1184.5 & \\
\hline & Treatment & Year & Interaction & Treatment & Year & Interaction \\
\hline LSD & 227.98 & 161.21 & 322.41 & 322.41 & 161.21 & 227.98 \\
\hline
\end{tabular}

old seedling while minimum gross margin $\mathrm{ha}^{-1}$ US (\$) 337.5 was recorded in direct sowing method (Table 4). The age of seedlings is one of the factors affecting the vegetables yield. The vegetables cultivated from seedlings produce earlier yields. Various researchers state that the age of vegetable seedlings affects the early and total yield not of all vegetables (McCraw and Greig, 1986). It is anticipated that the seedling age affects the average fruit weight; seedlings have greater average fruit weight (Jankauskiene and Brazaityte, 2005). The possible reason for maximum yield using seedlings rather than direct seeded crop seems to be greater number of profitable fruits produced per plant which might have direct involvement towards high fruit yield. This may be because of higher or improved biomass, accumulation of resources and improved water relationship in the plants. In case of younger seedlings there was lesser biomass and less storage of food in terms of solutes needed for cellular elongation and thus less vegetative extension, whereas, older seedlings were mature enough, thus, restraining vegetative extension (Shukla et al., 2011). Approximately, identical views have been reported by Salik et al. (2000) in tomato who also obtained maximum yield by using middle aged seedlings. On the other hand, $\mathrm{Naz}$ et al. (2005) obtained maximum yield by using younger seedlings whereas Montano-Mata and Nunez (2003) used older seedlings for maximum possible yield. Different researchers (Hasandokht and Nosrati, 2010; Orzolek, 2004) also stated that vegetables cultivated from older seedlings produced higher yields. These results are also in contrast with the outcomes of Choudhari and More
(2001). Though, according to Liptay (1987), the yields from the seedlings of different ages are same, in spite of the same yield from younger seedlings of cucumber. NeSmith (1994) also described lesser fruit yield in direct seeded zucchini squash than four weeks old seedlings. Maximum gross return and gross margin in older bitter gourd seedlings were endorsed to the higher fruit yield due to greater availability period and higher survival rate.

\section{CONCLUSION}

The results of this two-year's study showed that seedling transplantation was better than traditional direct seeded bitter gourd. Seedlings of 45-60 days old produced higher fruit yield, gross return and gross margin. Farmers may be recommended to transplant 45-60 days old seedlings for commercial bitter gourd production.

\section{REFERENCES}

Barber, S.A. and M. Silberbush, 1984. Plant Root Morphology and Nutrient Uptake. In: Roots, Nutrient and Water Influx and Plant Growth, Barber, S.A. and D.R. Bouldin (Eds.). ASA Special Publication, America, pp: 65-87.

Choudhari, S.M. and T.A. More, 2001. Fertigation, fertilizer and spacing requirement of tropical gynoecious cucumber hybrids. Acta Hort., 588: 233-240.

GOP., 2014. Fruits, vegetables and condiments: Statistics of Pakistan. Ministry of National Food Security and Research (Economic Wing), Islamabad. 
Hall, M.R., 1989. Cell size of seedling containers influences early vine growth and yield of transplanted watermelon. HortScience, 24: 771-773.

Handley, D. and M. Hutton, 2003. Effect of seeding date, transplant size and container on growth and yield of pickling cucumbers. J. Amer. Soc. Hort. Sci., 38: $672-672$.

Hasandokht, M.R. and S.Z. Nosrati, 2010. Effect of transplant age and fruit pruning on earliness and total yield of greenhouse cucumber (Cucumis sativus L. cv. Sultan). J. Plant Ecophysiol., 2: 21-25.

Jankauskiene, J. and A. Brazaityte, 2005. Influence of transplant age on the earliness of yield and productivity of short-fruit cucumbers. Sodininkyste Darzininkyste, 24: 138-146.

Leskovar, D.I. and P.J. Stoffella, 1995. Vegetable seedling root systems: Morphology, development and importance. HortScience, 30: 1153-1159.

Liptay, A., 1987. Field survival and establishment of tomato transplants of various age and size. Acta Hortic., 220: 203-210.

McCraw, B.D. and J.K. Greig, 1986. Effect of transplant age and pruning procedure on yield and fruit-set of bell pepper. HortScience, 21: 430-431.

McKee, J.M.T., 1981. Physiological aspects of transplanting vegetables and other crops. II. Methods used to improve transplant establishment. Hort. Abstr., 51: 355-368.

Montano-Mata, N.J. and J.C. Nunez, 2003. Evaluation of the effect of transplant age on yield in three selections of sweet pepper (Capsicum chinense Jack) in Jusepin, Monagas state. Revista-de-laFacultad-deAgronomia-Universidad-del-Zulia, 20: 144-155.

Naz, S., M. Amjad, B. Siddique and I. Ahmad, 2005. Effect of different ages of transplants on the yield of chillies. Ind. J. Plant Sci., 4: 332-335.

NeSmith, D.S. and J.R. Duval, 1998. The effect of container size. HortTechnology, 8: 495-498.
NeSmith, D.S., 1994. Transplant age has little influence on yield of muskmelon (Cucumis melo L.). HortScience, 29: 916-916.

NeSmith, D.S., G. Hoogenboom and D.W. Groff, 1994. Staminate and pistillate flower production of summer squash in response to planting date. HortScience, 29: 256-257.

Orzolek, M., 2004. Evaluating vegetable transplants: Virginia cooperative extension Virginia Vegetable, Small Fruit and Specialty Crops, Virginia State University, March-April, 2004.

Orzolek, M.D., 1996. Stand establishment in plasticulture systems. HortTechnology, 6: 181-185.

Palada, M.C. and L.C. Chang, 2003. Suggested cultural practices for bitter gourd. International Cooperators Guide, AVRDC Pub. No. 03-547, Taiwan.

Salik, M.R., F. Muhammad and M.A. Pervez, 2000. Relationship between age of seedlings on productivity of tomato (Lycopersicon esculentum L.) grown under plastic tunnel. Pak. J. Biol. Sci., 3: $1260-1261$.

Shukla, Y.R., T. Chhopal and R. Sharma, 2011. Effect of age of transplants on growth and yield of capsicum. Int. J. Farm Sci., 1: 56-62.

Singh, B., B.S. Tomar and M. Hasan, 2010. Plug tray nursery raising technology for off season cucurbits cultivation. Acta Hort., 871: 279-282.

Steel, G.D. and J.H. Torrie and D.A. Dickey, 1997. Principles and Procedures of Statistics: A Biometrical Approach. 2nd Edn., McGraw-Hill Book, New York, pp: 636.

Taylor, H.M. and G.F. Arkin, 1981. Root Zone Modification: Fundamentals and Alternatives. In: Modifying the Root Environment to Reduce Crop Stress, Arkin, G.F. and H.M. Taylor (Eds.). Amer. Soc. Agric. Eng., USA., pp: 3-17.

Weston, L.A., 1988. Effect of flat cell size, transplant age, and production site on growth and yield of pepper transplants. HortScience, 23: 709-711. 